\title{
Efficacy of different chemical and botanical insecticides in controlling mango hopper (Amritodusatkinsoni L.)
}

\begin{abstract}
To manage the mango hopper (Amritodusatkinsoni L) using five insecticides: three chemicals (Acetamiprid 20 SP, Q-fos $25 \mathrm{EC}$ and Confidor $70 \mathrm{WG}$ ) with 3 concentrations $(0.001 \%, 0.00125 \%$ and $0.0025 \%)$ and two botanicals (Neem extract and Mahogoniextract) with 3 concentrations $(0.5 \%, 1.0 \%$ and $1.5 \%)$ maintaining six replications of each to know their efficacy to control Mango hopper. Comparative efficacy of insecticides in the laboratory showed that all the three concentrations of Confidor $70 \mathrm{WG}(0.001 \%, 0.00125 \%$ and $0.0025 \%$ ) effectively controlled mango hopper (48.15\%) where Acetamiprid $20 \mathrm{SP}$ can kill $46.67 \%$ at the same concentrations on an average but it was found that Confidor $70 \mathrm{WG}$ can control $98.33 \%$ mango hopper while Acetamiprid $20 \mathrm{SP}$ can control $93.33 \%$ when these were applied at $0.0025 \%$ concentration and observed at 24 hours after treatment. Therefore, within two neo nicotinic insecticides Confidor 70 WG was superior in considering mortality percentage of mango hopper. Among the botanical insecticides, Azadirachtinebased Neem extract $1.5 \%$ was the best insecticide on an average than the Mahogoniextract for controlling the mango hopper but both of them showed moderate efficacy at $1.0 \%$ concentration for the3hours after treatment. Observation on the efficacy y of insecticides in managing mango hopper which will contribute in increasing mango yield showed that Confidor 70 WG $0.0025 \%$ effectively controlled mango hopper $(98.33 \%)$ among the chemical insecticides and Neem extract (1.5\%) showed higher efficacy than Mahogoniextract (1.5\%) among the botanicals.
\end{abstract}

Keywords: mango hopper, insecticides, hour after treatment (HAT), botanical insecticide
Volume 8 Issue 2 - 2018

\author{
Shawkat Islam Shawan, Rais Uddin Rashed, \\ Atiya Sharmin Mitu, Mahbuba Jahan \\ Bangladesh Agricultural University, Bangladesh
}

Correspondence: Rais Uddin Rashed, Bangladesh Agricultural University, Bangladesh, Email rurashed1987@gmail.com

Received: January 18,2018 | Published: March 09, 2018

\section{Introduction}

The most important species of Mango hoppers are Amritodusatkinsoni (Leth.), Idioscopusniveosparsus (Leth.) and Idioscopusclypealis (Leth.) which are found in Bangladesh. Among of them Amritodusatkinsoni has become the most damaging one. Mango hoppers have incomplete metamorphosis and pass three life stages such as egg, nymph and adult. Both the nymphs and adults of the hoppers puncture and suck the sap from tender shoots, inflorescences, and leaves of mango crop, which cause non-setting of flowers and dropping of immature fruits, thereby reducing the yield. Hoppers also excrete a secretion, called honey dew. In moist weather, it encourages the development of fungi like Meliolamangiferae (Earle), resulting in growth of sooty mould fungus on dorsal surface of leaves, branches, and fruits. This black coating interferes with the normal photosynthetic activity of the plant, ultimately resulting in non-setting of flowers and dropping of immature fruits. Under this circumstance, the present research was undertaken to manage mango hopper, Amritodusatkinsoni (Lethierry), using three non-persistence chemical insecticides, namely, Acetamiprid 20 SP, Q-fos 25 EC, Confidor 70 WG and two natural products Neem extract and Mahogoni extract. Neem based products have extensively been used and have proved their pest control efficacy against several insect pests both in field and storage Singh. ${ }^{1}$ This research work on mango hopper would provide significant information to protect the mango flower and leaves from the attack of the pest and thereby will increase the yields which ultimately increase the farmer's economy as well as the economy of the country. Mango hopper (Amritodusatkinsoni) is now a major constraint on mango production in Bangladesh Singh. ${ }^{2}$ On the basis of important aspects regarding its management strategy, this experiment was conducted to fulfill the following objectives:

a) To investigate the susceptibility of mango hopper to the selected chemical and botanical insecticides;

b) To find out the efficacy of different concentrations of selected insecticides in controlling the mango hopper in the laboratory test.

\section{Materials and Methods}

The experiment was carried out in the IPM laboratory of the Entomology Department, Bangladesh Agricultural University, Mymensingh, during February, 2014 to May, 2015.Since it is a laboratory-based study where different insecticide with different concentrations were applied in the same insect and the source of experimental data was homogenous in nature, the experiment was designed and analyzed in Completely Randomized Design (CRD). The chemical sample were collected from different agro-chemical company in Bangladesh.

\section{Collection of mango hopper and mango inflorescences}

The mango hoppers (Amritodusatkinsoni L.) and mango inflorescences (tender) were collected from the entomological field laboratory and horticultural field of Bangladesh Agricultural University, Mymensingh.

\section{Insecticides used in the experiment}

Five insecticides viz. three chemicals with 3 different concentrations and two botanicals with 3 different concentrations were evaluated 
for their efficacy against mango hopper (A. atkinsoni L.). The three chemical insecticides (Acetamiprid $20 \mathrm{SP}$, Q-fos $25 \mathrm{EC}$ and Confidor $70 \mathrm{WG}$ ) were applied at three different concentrations viz. $0.001 \%$, $0.00125 \%$ and $0.0025 \%$; and the two botanical insecticides (Neem extract and Mahogoni extract) were applied with 3 concentrations of $0.50 \%, 1.0 \%$ and $1.5 \%$ for each insecticide.

\section{Application of insecticides, data recording}

At first 95 petri dishes (12 cm diameter) were taken and disease free tender shoots of mango tree were collected. The healthy and tender inflorescence of mango tree was kept on the tissue paper in the petri dish. Insecticides were sprayed on the insects feeding on mango inflorescences supplied in each Petridis. Among the 95 petri dishes, (Insecticides*Concentrations*Replication) $=(5 \times 3 \times 6)=90$ petri dishes were used for treatments and 5 petri dishes were used for control against of the insecticide. Then 10 adult mango hoppers were supplied at each petri dish and each of the petri dish was covered after insecticidal spray. Here, five insecticides each with respective concentrations were sprayed to the adult mango hopper maintaining 6 replications $\left(R_{1}, R_{2}, R_{3} R_{4}, R_{5}\right.$ and $\left.R_{6}\right)$ for each insecticide and their respective concentrations. Insecticides were not sprayed for control to fulfill the experiment. The insecticides were sprayed to the selected petri dishes with dropper and all the necessary precautions were taken during insecticidal application. The number of dead hopper per infested mango inflorescences was counted at 1 hour, 3 hours and 24 hours after treatment\& mortality percentage (\%) was determined.

\section{Data analysis}

The obtained data on the number of hopper killed were analyzed statistically after appropriate transformation using analytical computer software Mstat, WASP and mean values were separated using DMRT. The graphical correlation and relationship between mortality of mango hopper and different concentrations of insecticide was constructed using MS Excel sheet (Figures 1-3).
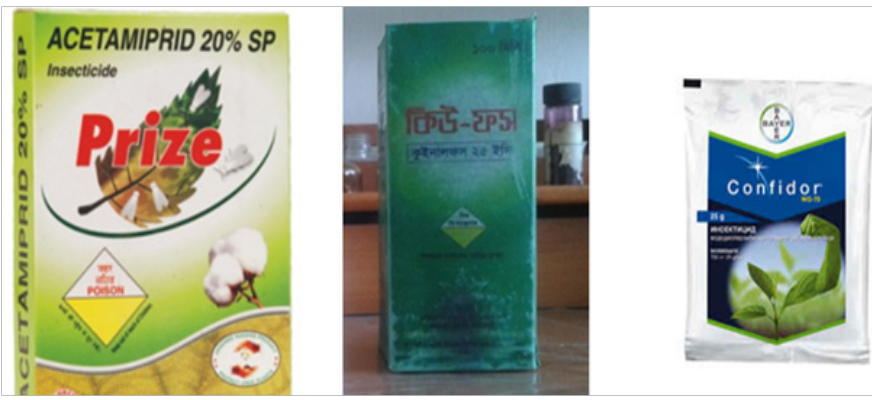

Figure I Chemical insecticides used in the experiment-Acetamiprid $20 \mathrm{SP}$, Confidor 70 WG, Q-fos 25 EC (Quinalfos 25 EC)

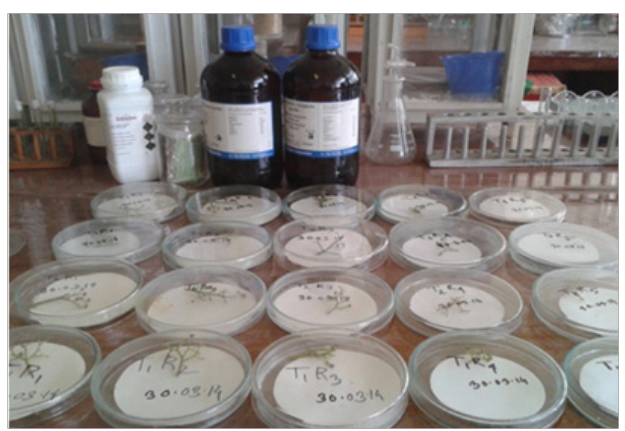

Figure 2 Insects feeding on mango inflorescences in petridishes and sprayed with insecticides.

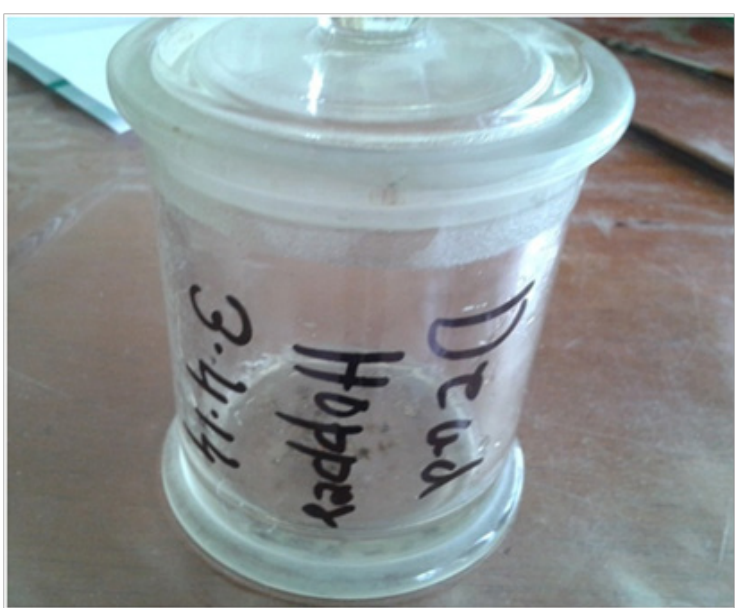

Figure 3 Dead insects (mango hopper) collected in glass container.

\section{Results and discussion}

The present experiment was carried out to investigate the effectiveness of different three chemical insecticides with 3 different concentrations and two botanical insecticides with 3 different concentrations for controlling the mango hopper (Amritodusatkinsoni L.).

\section{Mean performance of chemical insecticides on the mortality rate of mango hopper}

In case of average effect of three chemical insecticides on the mortality of mango hopper, the highest mortality $(85.56 \%)$ was found for Acetamiprid $20 \mathrm{SP}$ followed by Confidor $70 \mathrm{WG}(85.0 \%)$ and Q-fos 25 EC $(80.56 \%)$ at 24 HAT. The lowest mortality (11.11\%) was found for Acetamiprid 20 SP followed by Q-fos $25 \mathrm{EC} \mathrm{(12.22 \% )} \mathrm{and}$ Confidor $70 \mathrm{WG}(13.89 \%)$ at 1 HAT. Moderate mortality was found for all insecticides at 24 HAT (Table 1). Sarker ${ }^{3}$ also discussed the effectiveness of some insecticides which are related to this experiment.

Table I Mean performance of three selected chemical insecticides on the mortality of mango hopper

\begin{tabular}{llll}
\hline Insecticides & \multicolumn{4}{l}{$\begin{array}{l}\text { Average mortality of Mango hopper } \\
\text { (\%) at 3-time intervals }\end{array}$} \\
\hline & I HAT & 3 HAT & 24 HAT \\
\hline $\begin{array}{l}\text { Acetamiprid } \\
\text { 20 SP }\end{array}$ & II.II b & $43.33 \mathrm{a}$ & $85.56 \mathrm{a}$ \\
Q-fos 25 EC & $12.22 \mathrm{ab}$ & $46.67 \mathrm{a}$ & $80.56 \mathrm{a}$ \\
Confidor 70WG & $13.89 \mathrm{a}$ & $45.56 \mathrm{a}$ & $85.00 \mathrm{a}$ \\
Lsd (0.05) & 2.42 & 5.572 & 5.807 \\
SE & 0.85 & 1.96 & 2.04 \\
Max. & 13.89 & 46.67 & 85.56 \\
Min. & 11.11 & 43.33 & 80.56 \\
Mean & 12.41 & 45.18 & 83.71 \\
\hline
\end{tabular}

Mean performance of three concentrations of chemical insecticides on the mortality of mango hopper

In case of average effect of three concentrations of chemical insecticides on the mortality of mango hopper, the highest mortality 
(95.00\%) was found for $0.0025 \%$ insecticides followed by $0.00125 \%$ and $0.001 \%$ insecticides at 24 HAT (Table 2) Patel. ${ }^{4}$ also found the remarkable results by using another insecticide like Actara. The lowest mortalilty $(10.00 \%)$ was found for $0.001 \%$ insecticides followed by $0.00125 \%$ and $0.0025 \%$ insecticides at 1 HAT. Moderate mortality was found for all insecticides with $0.00125 \%$ concentration at 24 HAT (Table 2).

Table 2 Mean performance of different concentrations of chemical insecticides on the mortality of mango hopper

\begin{tabular}{llll}
\hline Concentrations (\%) & \multicolumn{3}{l}{$\begin{array}{l}\text { Average mortality of Mango } \\
\text { hopper (\%) }\end{array}$} \\
& I HAT 3 times interval \\
\hline 0.001 & 3 HAT & 24 HAT \\
0.00125 & $10.00 \mathrm{~b}$ & $30.56 \mathrm{c}$ & $73.33 \mathrm{c}$ \\
0.0025 & $11.67 \mathrm{~b}$ & $45.00 \mathrm{~b}$ & $82.78 \mathrm{~b}$ \\
Lsd $(0.05)$ & $15.56 \mathrm{a}$ & $60.00 \mathrm{a}$ & $95.00 \mathrm{a}$ \\
$\mathrm{SE}$ & 2.417 & 5.572 & 5.807 \\
Max. & 0.8486 & 1.956 & 2.039 \\
Min. & 15.56 & 60.00 & 95.00 \\
Mean & 10.00 & 30.56 & 73.33 \\
\hline
\end{tabular}

Mean performance of interactions between three chemical insecticides and three concentrations on the mortality of mango hopper

In case of average effect of 9 interactions between 3 chemical insecticides and 3 different concentrations on the mortality of mango hopper, the highest mortality (98.33\%) was found for the interaction of Confidor 70 WG with $0.0025 \%$ concentration and the lowest mortality for the interaction of Q-fos $25 \mathrm{EC}$ with $0.001 \%$ concentration at 24 HAT. The lowest mortality $(10.0 \%)$ was found for all insecticides with $0.001 \%$ concentration at 1 HAT (Table 3 ).

Table 3 Effect of interaction between chemical insecticides and their three concentrations on the mortality of mango hopper

\begin{tabular}{llll}
\hline \multirow{2}{*}{$\begin{array}{l}\text { Interaction } \\
\text { (Insecticide*Conc.) }\end{array}$} & \multicolumn{3}{l}{$\begin{array}{l}\text { Average mortality of Mango hopper } \\
\text { (\%) at 3-time intervals }\end{array}$} \\
\cline { 2 - 4 } & I HAT & 3 HAT & 24 HAT \\
\hline $\mathrm{I}_{1} \mathrm{C}_{1}$ & $10.00 \mathrm{c}$ & $26.67 \mathrm{~d}$ & $76.67 \mathrm{cde}$ \\
$\mathrm{I}_{1} \mathrm{C}_{2}$ & $10.00 \mathrm{c}$ & $43.33 \mathrm{bc}$ & $86.67 \mathrm{bc}$ \\
$\mathrm{I}_{1} \mathrm{C}_{3}$ & $13.33 \mathrm{bc}$ & $60.00 \mathrm{a}$ & $93.33 \mathrm{ab}$ \\
$\mathrm{I}_{2} \mathrm{C}_{1}$ & $10.00 \mathrm{c}$ & $31.67 \mathrm{~d}$ & $70.00 \mathrm{e}$ \\
$\mathrm{I}_{2} \mathrm{C}_{2}$ & $11.67 \mathrm{bc}$ & $48.33 \mathrm{~b}$ & $78.33 \mathrm{cde}$ \\
$\mathrm{I}_{2} \mathrm{C}_{3}$ & $15.00 \mathrm{ab}$ & $60.00 \mathrm{a}$ & $93.33 \mathrm{ab}$ \\
$\mathrm{I}_{3} \mathrm{C}_{1}$ & $10.00 \mathrm{c}$ & $33.33 \mathrm{~cd}$ & $73.33 \mathrm{de}$ \\
$\mathrm{I}_{3} \mathrm{C}_{2}$ & $13.33 \mathrm{bc}$ & $43.33 \mathrm{bc}$ & $83.33 \mathrm{bcd}$ \\
$\mathrm{I}_{3} \mathrm{C}_{3}$ & $18.33 \mathrm{a}$ & $60.00 \mathrm{a}$ & $98.33 \mathrm{a}$ \\
Lsd $(0.05)$ & 4.187 & 9.652 & 10.06 \\
SE & 1.470 & 3.388 & $3.53 \mathrm{I}$ \\
Max. & 18.33 & 60.00 & 98.33 \\
Min. & 10.00 & 26.67 & 70.00 \\
Mean & $12.4 \mathrm{I}$ & 45.18 & 83.70 \\
\hline
\end{tabular}

Here, I, Acetamiprid $20 \mathrm{SP} ; \mathrm{I}_{2}$, Q-fos $25 \mathrm{EC}$; I 3 , Confidor 70WG; $\mathrm{C}_{1}, 0.001 \% ; \mathrm{C}_{2}$, $0.00125 \% ; C_{3}, 0.0025 \%$; HAT, Hour after treatment; SE, Standard Error

\section{Mean performance of botanical insecticides on the mortality of mango hopper}

In case of average effect of two botanical insecticides on the mortality of mango hopper, the highest mortality (31.11\%) was found for Neem extract followed by Mahogoni extract (25.0\%) at 24 HAT. The lowest mortality $(5.56 \%)$ was found for Mahogoni extract followed by Neem extract $(6.67 \%)$ at 1 HAT Verghese, ${ }^{5}$ also found the azadirachtine can controlled the mango hopper effectively (Table 4).

Table 4 Mean performance of the selected two botanical insecticides on the mortality of mango hopper

\begin{tabular}{l|llc}
\hline \multirow{2}{*}{ Insecticides } & \multicolumn{3}{|c}{$\begin{array}{l}\text { Average mortality of Mango } \\
\text { hopper (\%) at 3 }\end{array}$} \\
\cline { 2 - 4 } & I HAT & 3 HAT & 24 HAT \\
\hline $\begin{array}{l}\text { Neem } \\
\text { extract }\end{array}$ & $6.67 \mathrm{a}$ & $17.22 \mathrm{a}$ & $31.1 \mathrm{I} \mathrm{a}$ \\
$\begin{array}{l}\text { Mahogoni } \\
\text { extract }\end{array}$ & $5.56 \mathrm{a}$ & $13.33 \mathrm{~b}$ & $25.00 \mathrm{~b}$ \\
Lsd $(0.05)$ & 2.79 & 3.29 & $4.5 \mathrm{I}$ \\
SE & 0.96 & 1.13 & 1.56 \\
Max. & 6.67 & 17.22 & $31.1 \mathrm{I}$ \\
Min. & 5.56 & 13.33 & 25.00 \\
Mean & $6.1 \mathrm{I}$ & 15.27 & 28.05 \\
\hline
\end{tabular}

Mean performance of three concentrations of botanical insecticides on the mortality of mango hopper

In case of average effect of three concentrations $(0.5 \%, 1.0 \%$ \& $1.5 \%)$ of botanical insecticides on the mortality of mango hopper, the highest mortality $(32.50 \%)$ was found for $1.5 \%$ insecticides followed by $1.0 \%$ and $0.5 \%$ insecticides at 24 HAT. The lowest mortality $(2.5 \%)$ was found for $0.5 \%$ insecticides followed by $1.0 \%$ and $1.5 \%$ insecticides at 1 HAT. Moderate mortality was found for all insecticides with $1.0 \%$ concentration at 3 HAT (Table 5).

Table 5 Mean performance of different concentrations of the botanical insecticides on the mortality of mango hopper

\begin{tabular}{l|lll}
\hline \multirow{2}{*}{ Concentrations (\%) } & \multicolumn{3}{l}{$\begin{array}{l}\text { Average mortality of Mango } \\
\text { hopper (\%) }\end{array}$} \\
\cline { 2 - 4 } & I HAT & 3 times interval \\
\hline 0.5 & $2.500 \mathrm{~b}$ & $11.67 \mathrm{~b}$ & 24 HAT \\
\hline I.0 & $5.833 \mathrm{~b}$ & $14.17 \mathrm{~b}$ & $28.33 \mathrm{~b}$ \\
$\mathrm{I} .5$ & $10.00 \mathrm{a}$ & $20.00 \mathrm{a}$ & $32.50 \mathrm{a}$ \\
Lsd $(0.05)$ & 3.404 & 3.979 & 5.524 \\
SE & 1.179 & 1.378 & 1.912 \\
Max. & 10.00 & 20.00 & 32.50 \\
Min. & 2.500 & 11.67 & 23.33 \\
Mean & 6.11 & 15.28 & 28.05 \\
\hline
\end{tabular}

Mean performance of interactions between two botanical insecticides and three concentrations on the mortality of mango hopper

In case of average effect of 6 interactions between 2 botanical insecticides and 3 different concentrations on the mortality of mango hopper, the highest mortality (35.0\%) was found for the interaction of 
Neem extract with $1.5 \%$ concentration and the lowest mortality for the interaction of Mahogoni extract with $0.5 \%$ concentration at 24 HAT. The lowest mortality (1.67\%) was found for Mahogoni extract with $0.5 \%$ concentration at 1 HAT (Table 6 ). Kumar. $^{6}$ also mentioned the same results by using neem extract.

Table 6 Mean performance of the interaction between insecticides and their concentrations on the mortality of mango hopper

\begin{tabular}{l|lll}
\hline \multirow{2}{*}{$\begin{array}{l}\text { Interaction } \\
\text { (Insecticide*Conc) }\end{array}$} & \multicolumn{3}{l}{$\begin{array}{l}\text { Average mortality of Mango } \\
\text { hopper (\%) at 3 times interval }\end{array}$} \\
\cline { 2 - 4 } & I HAT & 3 HAT & 24 HAT \\
\hline $\mathrm{I}_{1} \mathrm{C}_{1}$ & $3.33 \mathrm{~b}$ & $13.33 \mathrm{bc}$ & $26.67 \mathrm{abc}$ \\
$\mathrm{I}_{1} \mathrm{C}_{2}$ & $6.667 \mathrm{ab}$ & $15.00 \mathrm{bc}$ & $31.67 \mathrm{ab}$ \\
$\mathrm{I}_{1} \mathrm{C}_{3}$ & $10.00 \mathrm{a}$ & $23.33 \mathrm{a}$ & $35.00 \mathrm{a}$ \\
$\mathrm{I}_{2} \mathrm{C}_{1}$ & $1.667 \mathrm{~b}$ & $10.00 \mathrm{c}$ & $20.00 \mathrm{c}$ \\
$\mathrm{I}_{2} \mathrm{C}_{2}$ & $5.000 \mathrm{ab}$ & $13.33 \mathrm{bc}$ & $25.00 \mathrm{bc}$ \\
$\mathrm{I}_{2} \mathrm{C}_{3}$ & $10.00 \mathrm{a}$ & $16.67 \mathrm{~b}$ & $30.00 \mathrm{ab}$ \\
$\mathrm{Lsd}_{2}(0.05)$ & 4.814 & 5.627 & $7.81 \mathrm{I}$ \\
$\mathrm{SE}$ & 1.667 & 1.948 & 2.705 \\
Max. & 10.00 & 23.33 & 35.00 \\
Min. & 1.667 & 10.00 & 20.00 \\
Mean & 6.11 & 15.27 & 28.05 \\
\hline
\end{tabular}

Here, I, Neem extract; $I_{2}$, Mahogoni extract; $C_{1}, 0.5 \% ; C_{2}, 1.0 \% ; C_{3}, 1.5 \%$

\section{Comparative effects of five insecticides and three concentrations on the mortality of mango hopper}

The mortality percentages of mango hopper (Amritodusatkinsoni L.) by three chemical insecticides with three different concentrations and two botanical insecticides with different concentrations at three different time intervals were recorded. Among the three chemical insecticides, the highest mortality of mango hopper (98.33\%) was found for $0.0025 \%$ Confidor $70 \mathrm{WG}$ at $24 \mathrm{HAT}$ and the lowest mortality $(10.0 \%)$ was found for $0.001 \%$ Acetamiprid $20 \mathrm{SP}$ at 1 HAT (Figure 4). In case of two botanical insecticides the highest mortality of mango hopper $(35.0 \%)$ was found for $1.5 \%$ Neem extract at 24 HAT and the lowest mortality $(1.67 \%)$ was found for $0.5 \%$ Mahogoni extract at 1 HAT (Figure 4). ${ }^{5}$ Reported that, the neem product azadirachtin controls the mango leaf hopper $(30 \%)$ with the application at $3 \%$ concentration. Maximum (98.33\%) live insects were found for $0.5 \%$ Mahogoni extract at $1 \mathrm{HAT}$ and minimum live insects (1.67\%) for $0.0025 \%$ Confidor $20 \mathrm{SP}$ at $24 \mathrm{HAT}$ (Figure 5); Patel $^{7}$ also discussed that the efficacy depends on the biology of the insects. In respect of ecological aspect, botanical insecticides are more eco friendly with our environment than the chemical insecticides. If we want to grow different crops and vegetables without any harmful elements in them, we have to choose the botanical insecticides for controlling different pests. ${ }^{7}$ conducted a field trial to evaluate the efficacy Six insecticides, namely Karate (lamda cyhalothrin) 2.5 EC, Classic (fenvalerate) 20 EC, Velafen (fenvalerate) 20 EC, Actara (thiamethoxam) 25 WG, Shobicron (cypermethrin/profenofos Q) 425 EC and Magic (cypermethrin) $10 \mathrm{EC}$ were evaluated at pre-determined doses. Two sprayings, the first within 10 days of flowering and the second after one month of the first application were done. Considering the percent reduction of adult and nymphal population over the pre-treatment population of the mango leaf hoppers and percent increased fruit retention over untreated control, Karate @ 1.0ml/litre of water, Actara (a) 5.0g/1001itre of water, Magic @ 1.0ml/litre of water, Shobicron (a) 1.0 ml/litre of water and Velafen @ $0.5 \mathrm{ml} /$ litre of water were the best among the tested insecticides for the effective control of mango leaf hoppers. Kumar et al. ${ }^{8}$ and Kumar et al. ${ }^{9}$ studied the bio efficacy of newer insecticides against hopper complex on Alphonso mango in humid topics of South Gujarat. They used four newer insecticides, imidacloprid (Confidor 200 SL, 0.005\%), thiamethoxam (Actara 25 WG; 0.0084\%), Profenophos (Curacron50 EC; 0.1\%) and lamdacyhalothrin (Karate 5EC; $0.003 \%$ ), along with ready mix insecticides i.e. Profenophos + Cypermethrin (Polythrin-C 44 EC; 0.044\%), and Chlorpyriphos + Cypermethrin (Nurelle-D 55 EC; 0.065\%),

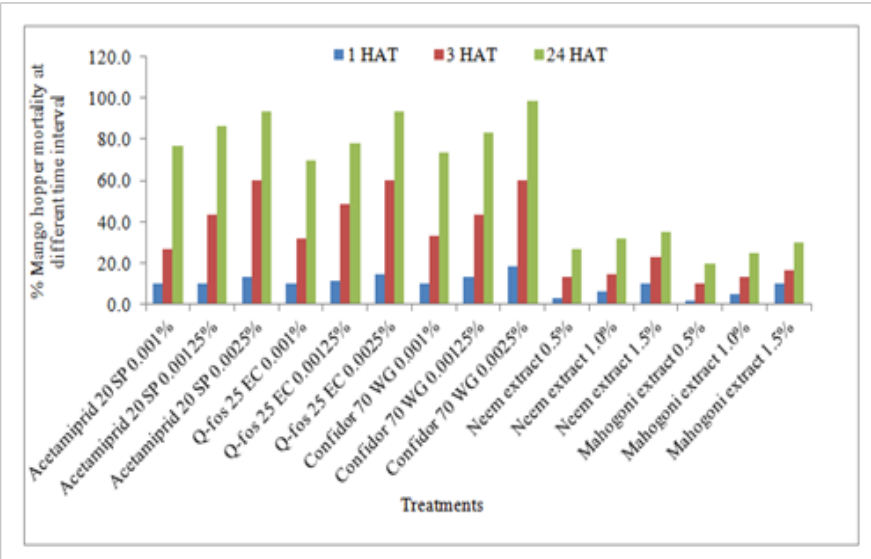

Figure 4 Susceptibility of mango hopper to different insecticides with different concentrations.

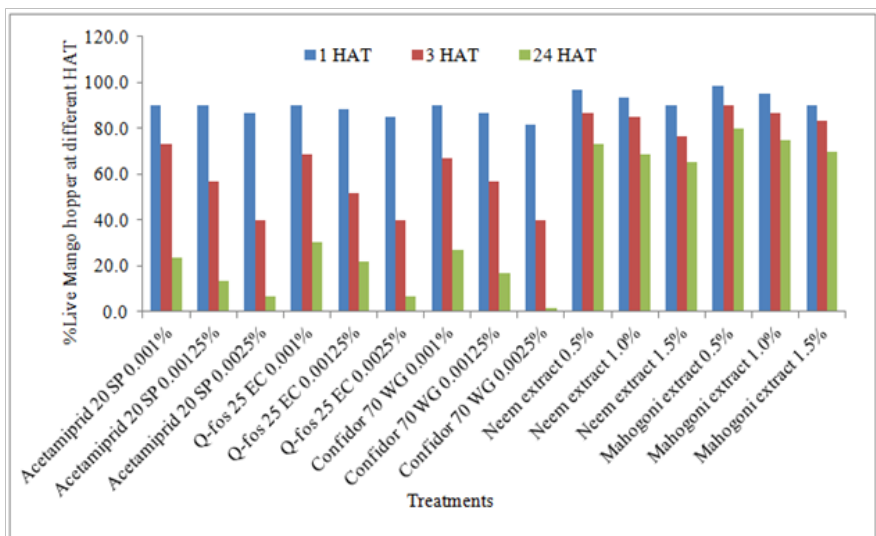

Figure 5 Live mango hopper (\%) at different hours after treatment with different concentrations of different insecticides.

\section{Summary and conclusion}

The mortality of mango hopper was significantly different among three different concentrations of Acetamiprid $20 \mathrm{SP}$ and ranged from $26.67 \%$ to $60.0 \%$ at 3 HAT, $76.67 \%$ to $93.33 \%$ at 24 HAT. Among the three concentrations of Acetamiprid 20 SP the highest mortality of mango hopper was found at $0.0025 \%$ concentration at 24 HAT and lowest at $0.001 \%$ concentration at 1 HAT. Q-fos 25 EC (a) $0.0025 \%$ has high efficacy in controlling mango hopper. Among the three concentrations of Confidor $70 \mathrm{WG}$, the highest mortality of mango hopper $98.33 \%$ was found at $0.0025 \%$ concentration at 
24 HAT and lowest mortality $(10.0 \%)$ at $0.001 \%$ concentration. The highest mortality of mango hopper $35.0 \%$ and $30.0 \%$ were found with the application of Neem extract and Mahogoni extract for $1.5 \%$ concentration at 24 HAT and lowest $3.33 \%$ and $1.67 \%$ were found for $0.5 \%$ concentrations at 1 HAT respectively. Although all the insecticides had a remarkable effect on mango hopper, the overall effect of the chemical insecticides. From this experiment it can be concluded for chemical insecticides that, Confidor 70 WG can be recommended firstly followed by Acetamiprid $20 \mathrm{SP}$ and Q-fos 25 EC rate of $0.0025 \%$ concentration. For the treatment with botanical insecticides, the highest mortality (35.0\%) of mango hopper was found for $1.5 \%$ Neem extract at 24 HAT and minimum mortality (1.67\%) for $0.5 \%$ Mahogoni extract at 1 HAT. Average mortality for Neem extract was $31.11 \%$ and $25.0 \%$ for Mahogoni extract at 24 HAT. In respect of ecological aspect, botanical insecticides are more eco friendly with our environment than the chemical insecticides. The effectiveness of all the three chemicals and two botanical insecticides against mango hopper increased considerably with the increase of concentrations and times through mortality percent observation.

\section{Acknowledgement}

None.

\section{Conflict of interest}

None.

\section{Referencess}

1. Singh G. Efficacy of neem formulations compared to chemical insecticides against hoppers and leaf webber. Proceeding of the 6 International Symposiums on Mango. Acta Horticulture. 2000:509.
2. Singh G. Management of major mango insects affecting flowering and fruiting with some newer insecticides. Proceeding of the $2^{\text {nd }}$ international Symposium on Mango. Acta Horticulture. 1989:231.

3. Sarker D, Rahaman MM, Barman JC. Effectiveness of some insecticides for the control of mango leaf hoppers. Bangladesh J Entom. 2005;15(1):8992 .

4. Patel NC, Kher RH, Chavda AJ, et al, Bio-efficacy of Thiamethoxam(Actara $25 \mathrm{WG}$ ) in comparison to conventional insecticides against hopper, Amritodusatkinsoni in festing mango. Indian $J$ Ent. 2003;65(3):315-318.

5. Verghese A. Effect of imidacloprid, lambda-cyhalothrin and azadirachtin on the mango hopper, Idioscopusniveosparsus (Leth.) (Homoptera: Cicadellidae). Proceedings of the sixth international symposium on mango. Acta Horticulturae. 2000;509(2):733-736.

6. Kumar S, Bhatt RI. Field evaluation of plant leaf extracts, oil and neem products against mango hopper (Amritodusatikinsoni Lethierry) and thrips (Scirto thripsmangiferae H.). Allelopathy, Gujarat Agril. University, Gujarat, India. J Agriculture Experimental Station. 1999;6(10):271-276.

7. Patel RK, Patel SR, Shah AH. Biology of mango hopper, Amritodusatkinsoni (Leth.). (Jassidae: Homoptera) in south Gujrat. Indian J Entom. 1975;37(2):150-153.

8. Kumar S, Raghvani BR, Bhatt RI. Bioefficacy of newer insecticides against hopper complex on Alphonso mango in humid tropics of south Gujarat. $J$ Appl Zoological Res. 2005;16(1):64-66.

9. Kumar S, Bhatt RI, Kumar S. Pyrethroid-induced resurgence of sucking pests in the mango eco-systyem. Agriculture Experimental Station (AES), Gujrat Agricultural University, India, 2002. 